\title{
Social Media Networks as Revolutionary Tools for Regime Change: Reflections on the 2011 Civil Unrest in Egypt
}

\author{
${ }^{1}$ Dr. Odoh, S.I., ${ }^{2}$ Nwogbaga, David M. E. \\ ${ }^{I}$ Political Science Department Ebonyi State University Abakaliki \\ ${ }^{2}$ Political Science Department Ebonyi State University Abakaliki
}

\begin{abstract}
The tendency by governments to censor Internet operations especially in times of crisis as witnessed in some countries of the Middle East and North Africa, has evoked considerable concern among civil rights groups across the globe over the threats against online activism for regime change. It is feared that the same technical measures could be applied in other countries in similar emergency situations. There have been predictions that the Internet would serve as a regime-changing tool for the masses especially against totalitarian governments; but there are also arguments to the contrary. While the Optimists opine that the Internet is a veritable revolutionary tool for regime change given its efficacy in quick information dissemination for mass mobilisation; the Pessimists contend that the Internet is not an effective instrument of regime change due to high level of government censorship. In the light of Egypt's civil unrests, we examined the rights of the citizens and the government in the use of the internet for online activism as well as the extent to which the internet can facilitate regime change. We argued that the internet plays critical roles in causing regime change; however, in as much as the citizens have their rights to use the internet for online activism, the government also has the obligation to regulate and control the use in the interest of national security, but not to the extent of shutting down the entire internet operating system of a country. It is therefore recommended that instead of the government to use technical measures to censor the citizens internet operations, they should rather apply legal options.
\end{abstract}

\section{Introduction}

The Internet has expanded from an academic curiosity into a piece of political infrastructure in the world. Its rate of expansion has been staggering faster than television, radio or the telephone system. Part of the reason for this expansion has been the open operation of the Internet. The Internet has played a role in civil unrest and regime change in many countries over recent years, to the extent that governments under pressure from citizens have sometimes censored the internet operations in their territories. The Tunisian Revolution, along with the civil unrests in Egypt and Libya, have sparked a wave of major uprisings in other parts of the world like Algeria, Bahrain, Iran, Jordan, Morocco,Yemen, and Syria. In addition, minor incidents have occurred in Iraq, Kuwait, Mauritania, Oman, Saudi Arabia, Somalia, and Sudan. These protests were engineered mainly through the internet. The various governments have embarked on varying degrees of extensive Internet censorship and in some cases comprehensive to the extent of shutting down the entire internet operating system. It is therefore an issue of concern to explore how the Internet has been employed as a revolutionary tool for regime change as well as the rights of the citizens and the state's obligations in the use of the Internet for political purposes. Hence, we are focused on responding to the following questions: (1)What are the rights of the citizens and the government's obligation in the use of the Internet to realise political objectives? (2) To what extent did the internet contribute in generating the civil unrest for regime change in Egypt?

\section{Literature Review}

The emergence of rapid communications, especially the Internet, is seriously changing the dimensions of civil unrests and regime changes around the world. Internet censorship has also been extensive, and in some cases extended to taking entire nation-states practically off-line. In the early days of the Internet, its users argued that governments should have no place in controlling it. But later, the citizens began to make appeals that governments should pass laws against various forms of cybercrimes. The situation is complicated by the transnational nature of the internet which its operations extend beyond the effective regulation and control of any one government without the cooperation of another. This is more critical with the use of the internet as a revolutionary tool for mobilizing both national and international supports. In this section, we examined the rights of the citizens and the obligations of the government in the use of the internet as an instrument for political change; we also reviewed the internet as a social media for online activism. 


\section{The Citizens' Rights and Government's Obligation in the use of Internet}

In view of how the internet empowers the Citizens who use the internet, otherwise called "Netizens" (Users of the Net) in online activism, and the extent to which it threatens governments into taking some questionable measures, we shall look at what obligations governments have to deny the users, of Internet services, and what the users can do in such circumstances within the ambits of cyber-laws. Does the government have a legitimate role in limiting access to information and its dissemination through the internet? If yes, what forms of regulations are acceptable? Is it legal regulation or technical regulation or both?

Cyber-laws encapsulate the legal issues related to use of communicative, transactional, and distributive aspects of networked information devices and technologies. It is a set of legal enactments construed in several countries to govern the process and dissemination of information digitally. These legal enactments cover a broad range of different aspects relating to computer software, protection of computer software, access and control of digital information, privacy, security, internet access and usage, and electronic commerce. These have been described more or less as "Paper laws" for "paperless environment".

In various countries, areas of the computing and communication industries are regulated - often strictly by government bodies. There are rules on the uses to which computers and computer networks may be put, in particular there are rules on unauthorized access, data privacy, information dissemination, and spamming etc. Hence, the rights of the citizens and the governments in the use of the Internet border on: Privacy, freedom of expression, neutrality, regulation and censorship, as well as Jurisdiction and sovereignty. Observably, several countries had not enacted laws in these respects due the novelty of the use of the internet for online activism. As a result, there have been legal and technical battles between the netizens and the governments of different states on usage rights and limitations.

The privacy of an individual is directly affected by the collection, maintenance, use, and dissemination of personal information by government agencies; and that though the increasing use of computers and sophisticated information technology are essential to the efficient operations of the Government, it greatly magnified the harm to individual privacy that can occur from any collection, maintenance, use, or dissemination of personal information. The US Foreign Intelligence Surveillance Act (FISA) of 1978 for instance, established standards and procedures for use of electronic surveillance to collect "foreign intelligence" within the United States. This FISA overrides the 1986 Electronic Communications Privacy Act during investigations when foreign intelligence is "a significant purpose" of the said investigation.

Besides the question of privacy, there is also the issue of freedom of expression. Article 19 of the Universal Declaration of Human Rights calls for the protection of free expression in all media. In comparison to traditional print-based media, the accessibility and relative anonymity of cyber space has torn down traditional barriers between an individual and his or her ability to publish. Any person with an internet connection has the potential to reach an audience of millions with little-to-no distribution costs. Yet this new form of highly accessible authorship in cyber space raises questions and perhaps magnifies legal complexities relating to the freedom and regulation of speech in cyberspace as to curtail speeches that are capable of either marring the image of, or threatening, the government. Thus, the question of privacy and freedom of expression partly establishes that though the netizens have the rights, there are limitations attached therewith especially if the activities of the internet users are percieved as threats to the government. But at times, government responses towards addressing such threat situations are questioned on the basis of legality as they often go beyond constitutional measures.

Another major area of interest is net neutrality, which affects the regulation of the infrastructure of the Internet. Though not obvious to most Internet users, every packet of data sent and received by every user on the Internet passes through routers and transmission infrastructure owned by a collection of private and public entities, including telecommunications companies, universities, and governments, suggesting that the Internet is not as independent and secret as often believed. This is turning into one of the most critical aspects of cyberlaw and has immediate jurisdictional implications, as laws in force in one jurisdiction have the potential to have dramatic effects in other jurisdictions when host servers or telecommunications companies are affected. The issue of concern here is wether the host servers or telecommunication companies should maintain neutrality between the netizens and the government by not disclosing the contents of their online transactions in all circumstances or should they take sides with the government in transmitting private information against the wishes of the users especially when state security is under threat. This question of net neutrality will be determined better under the basis of internet regulation and censorship.

In relation to regulation and censorship, it is essential to note that the Internet has unique structure that has raised several judicial concerns. While grounded in physical computers and other electronic devices, the Internet is independent of any geographic location. Though individuals connect to the Internet and interact with others, it is possible for them to withhold personal information and make their real identities anonymous. If there are laws that could govern the Internet, then it appears that such laws would be fundamentally different from laws that geographic nations use today. Jonson and Post (2005) offered a solution to the problem of 
Internet governance. Given the Internet's unique situation, with respect to geography and identity, Johnson and Post (2005) believe that it becomes necessary for the Internet to be self-regulatory. Instead of obeying the laws of a particular country, Netizens (Internet citizens or users) should obey the laws of electronic entities like Service Providers. Instead of identifying as a physical person, the netizens will be known by their usernames or email addresses. Since the Internet defies geographical boundaries, national laws may no longer apply; instead, an entirely new set of laws will be created to address concerns like individual rights relating to the use of the internet. In effect, the Internet will exist as its own "Sovereign Entity". But, even if the Internet represents a legal paradigm shift, Johnson and Post (2005) did not make clear exactly how or by whom the laws of the Internet will be made and enforced. Apart from the most obvious examples of internet filtering in nations like China, Saudi Arabia or Iran etc (that monitor Internet contents and trafficks), there are three primary modes of regulating internet operations (Lessig, 2000): the legal, the technical, and the ethical measures measures.

The legal measures provided for many actions on the internet subject to conventional legislation (both with regard to transactions conducted on the internet and images posted). Hence, it is certainly clear that substantial portions of internet activity are subject to traditional regulation, and that conduct that is unlawful offline is presumptively unlawful online, and subject to similar laws and regulations.

In terms of Technical Measures, the mechanisms concern the parameters of how information can and cannot be transmitted across the internet. Everything from internet filtering software [which searches for keywords or specific URLs (Uniform Resource Locators) and blocks them before they can even appear on the computer requesting them], encryption programs, and the very basic architecture of TCP (Transmision Control Protocols) and IP (Internet protocol), fall within technical measures of regulation.

Ethical Measures on the other hand rely on the established norms of social interaction. Conducts are regulated by social norms and conventions in significant ways. While certain activities or kinds of conduct online may not be specifically prohibited by the code architecture of the internet, or expressly prohibited by applicable law, these activities or conduct will be invisibly regulated by the inherent standards of the community, in this case the internet "users." And just as certain patterns of conduct will cause an individual to be ostracised from our real world society, so too certain actions will be censored or self-regulated by the norms of whatever community one chooses to associate with on the internet: be it Twitter, Facebook, or YouTube.

The question of Internet censorship is also very critical. In many countries, speech through cyberspace has proven to be another means of communication which has been regulated by the government due to its sensitivity in the internet environment. The Open Net Initiative whose mission statement is "to investigate and challenge state filtration and surveillance practices" to "...generate a credible picture of these practices," has released numerous reports documenting the filtration of internet-speech in various countries. While China has thus far proven to be the most rigorous in its attempts to filter unwanted parts of the internet from its citizens (Open Net Initiative, 2011), many other countries - including Singapore, Iran, Saudi Arabia, and Tunisia - have engaged in similar practices of Internet censorship. In one of the most vivid examples of information control, the Chinese government for a short time transparently forwarded requests to the Google search engine to its own, state-controlled search engines.

The issues of jurisdiction and sovereignty quickly came to the fore in the era of the Internet due to the transnational extension of internet operations beyond the control and usage by any one government to the exclusion or detriment of another. This is particularly problematic as the medium of the Internet does not explicitly recognize sovereignty and territorial limitations. There is no uniform, international jurisdictional law of universal application, and such questions are generally a matter of conflict of laws, particularly private international law. An example would be where the contents of a website are legal in one country and illegal in another. In the absence of a uniform jurisdictional code, legal practitioners are generally left with a conflict of law issue. Essentially, the Internet does not tend to make geographical and jurisdictional boundaries clear, but Internet users remain in physical jurisdictions and are subject to laws independent of their presence on the Internet (Trout, 2007). As such, a single transaction may involve the laws of at least three jurisdictions (Trout, 2007):

1. The laws of the state/nation in which the user resides;

2. the laws of the state/nation that apply where the server hosting the transaction is located; and

3. the laws of the state/nation which apply to the person or business with whom the transaction takes place.

For instance, a user in Nigeria conducting a transaction with another user in Britain through a server in Canada could theoretically be subject to the laws of all three countries as they relate to the transaction at hand (Raysman et al, 2008). But, in practical terms, a user of the Internet is subject to the laws of the state or nation within which he or she goes online.

Meanwhile, private internet users have the rights to:

1. Privacy

2. Freedom of Expression 
3. Access information

But in order to control the internet activities of the users, the government is also obliged to:

1. Regulate their internet operations of the users

2. Censor the contents of their online transmissions

3. Make and enforce cyberlaws against cybercrimes

However, the control of the internet activities of the users by the government should be by legal means rather than technical means like shutting down the internet system entirely because it cripples all online transactions and affects the business of foreigners who are not the primary targets.

\section{The Role of the Internet as a Social Media in Online Activism}

The use of the internet as social media for online activism and political change has been extensive. It has ranged mainly from facebook interactions, to twitters, and YouTube. These social media have been used for various forms of social activism such as sensitisation, campaigns, debates, and mobilisations in different countries like Iran, Tunisia, Egypt, Libya, Morocco and Yemen etc. The effects of their uses have generated conflicts of different kinds especially between civil right groups and the citizens with the government.

Facebook is a social networking service and website founded by Mark Zuckerberg with his college roommates and fellow computer science students: Eduardo Saverin, Dustin Moskovitz and Chris Hughes. It was launched in February 2004, operated and privately owned by Facebook, Inc. With about 600 million users and $3.57 \%$ monthly growth as at January 5, 2011 (Carlson, 2011). Users may create personal profiles, add other users as friends, and exchange messages, including immediate notifications of any emergency social activity. Users may join common-interest user-groups, organized by workplace, school or college, or other characteristics. The name of the service stems from the colloquial name for the book given to students at the start of the academic year by university administrations in the United States to help students get to know each other better. Facebook has affected the social life and activity of people in various ways. It can reunite lost family members and friends. Facebook users take part in debate groups organized around specific topics, register to vote, and message questions. Thus, Facebook is an extremely popular and essential new way to interact and voice opinions. Facebook has met some controversies which made it to be blocked intermittently in several countries including the People's Republic of China, Vietnam, Iran, Uzbekistan, Pakistan, Syria, and Bangladesh on different bases. For example, it was banned in many countries of the world on the basis that it allowed content judged as anti-Islamic and containing religious discrimination. It has also been banned at many workplaces to prevent employees wasting their time on the site.

Similarly, Twitter is a website based in San Francisco, owned and operated by Twitter Inc., which offers a social networking and micro-blogging service, enabling its users to send and read messages called tweets. Tweets are text-based posts of up to 140 characters displayed on the user's profile page. It was produced in March 2006 by Jack Dorsey and launched in July. Since then, Twitter has gained popularity worldwide and is estimated to have 200 million users, generating 190 million tweets a day and handling over 1.6 billion search queries per day (Cloud, 2006; Weber, 2007). It is sometimes described as the "SMS of the Internet". Twitter has been used for a variety of purposes in many different industries and scenarios. For example, it has been used to organize protests, sometimes referred to as "Twitter Revolutions" and which include the 2011 Egyptian protests, 2010-2011 Tunisian protests, 2009-2010 Iranian election protests, and 2009 Moldova civil unrest (BBC, 2011). The service has also been used in emergencies and political campaigning. It is also used for direct communication among social groups and organizations. Twitter has however been censored in Iran, China, Egypt, and South Korea for perceived anti-government activities of the users.

On the other hand, YouTube is a video-sharing website on which users can upload, share and view videos of various kinds. YouTube was founded in February 2005 by Chad Hurley, Steve Chen, and Jawed Karim, who were all early employees of PayPal (Hopkins, 2006). The company is based in San Bruno, California. The technology is used to display a wide variety of user-generated video content, including movie clips, TV clips, and music videos, as well as amateur content such as video blogging and short original videos. Over 48 hours of new videos are uploaded to the site every minute. YouTube made it possible for anyone with an Internet connection to post a video that a worldwide audience could watch within a few minutes especially in crisis period. The wide range of topics covered by YouTube has turned video sharing into one of the most important parts of Internet culture. YouTube has been censored in China, Morocco, Thailand, Turkey, Pakistan, Iran, Libya and Egypt to stop publications of true pictures of crisis situations like killings etc, which are capable of destroying a government's image.

Meanwhile, the Internet is a veritable revolutionary tool for regime change given its efficacy in quick information dissemination for mass mobilisation (Guerra, 2011). In view of this, the optimists advocate for internet freedom and rights of individuals and groups to access networked technologies without restraints especially by government. If government must censor the social media for online activism, it should be done through legal than technical measures as not to stifle positive efforts towards resolving such a crisis situation. 
However, the Pessimists such as Alayin (2011), Morozov (2011), expressed scepticism of the Internet's power to foster democracy. They contend that the Internet is not an effective instrument of regime change due to high level of government censorship. Morozov (2011), who studies the Internet's effect on authoritarian states, noted that the evolution of social media actually has aided oppressive regimes. In their view, the Internet has given dictators the ability to mine contents of social networking sites to identify dissidents and to pay bloggers for spreading propaganda.

Without prejudice to the contending perspectives, activists are beginning to understand the shortcomings of the Internet as a tool for bringing about changes in regimes. It is observable that democratic activism spurred by the ease of blogging and other Internet communication facilities has limits evidenced in Governments' repressive reactions. Authoritarian regimes have learned how to block certain computers from accessing the Internet (Guerra, 2011). One of the more effective ways to overcome these obstacles is to educate citizens on how to safely use Internet circumvention tools such as proxies that hide citizens' locations (Guerra, 2011). It should be noted that the Internet is not the first free speech facilitator to fall short of expectations. It was observed that since the Cold War, Radio Free Europe (RFE)/Radio Liberty (RL), the U.S.-funded broadcaster, has used shortwave frequencies to report news to countries that ban free press (Guerra, 2011). But throughout history, oppressive regimes have countered with espionage and misinformation campaigns to discredit the broadcasts. The Soviet KGB and Warsaw Pact Intelligence Services penetrated the stations, jailed sources and even resorted to violence in attempts to intimidate RFE and RL staff. Meanwhile, Dictators will always be able to find countermeasures, such as the Internet-filtering tools and online surveillance that China uses, to exert control over its people in the use of the Internet. In response, the internet service providers could divert users of its search engine to another location. For instance, Google diverted its search engine from China to Hong Kong's Google search service when the company discovered that hackers allegedly from China had attempted to penetrate the e-mail accounts of human rights activists.

Essentially, it was reported that USA has planned regime change for the past three years through human rights activists especially in the Middle East and North Africa (Staff-writer, 2011). The Bush Administration allegedly wanted to bring about a regime change in some countries (Libya, Bahrain, Yemen, Algeria, Jordan, Iran, Morocco, and Oman), five years after the 9/11 attacks in the US. This was a part of the Defence Department's strategy. But USA is not in position of further deployment of its military resources in this region (proper invasion on state); so strategists used internet and social networking sites as a tool for fulfilling their vested interests and became successful in bringing the masses on streets and forced to topple down governments. This internet revolution brought down two governments within a month. First in Tunis, propagandist sat behind the computer screens, fully exploited the situations, and incited the masses. The same technique was used in Egypt. The two events may not be viewed separately. When Egyptian government shut down the access to the internet so that the protestors could not communicate; ironically, the US president, Barrack Obama urged Egypt to restore back the access to internet, especially the social media website, "Face Book, Twitter, and you tube" (Ashfaq, 2011). In Tunisia, they were successful in removing Zainul Abdine, who finally took refuge in Saudi Arabia. Then this chaos shifted to Egypt. Despite being a US ally, Hosni Mubarak was forced to leave government. Even Europeans and Israel were in favour of his respectful removal but ironically, for US, the protestors were more important. Muhammad El Baradei the main opposition leader in Egypt, famous for providing evidence against Pakistan for nuclear proliferation and interestingly is in the board of Trustees of the International Crises Group, which is funded by Bill and Melinda Gates is a staunch US supporter. The foregoing expositions suggest that the US is behind the civil unrests in different countries especially in the Middle East and North Africa where there are authoritarian regimes.

\section{Reflections on the 2011 Civil Unrest for Regime Change in Egypt}

The 2011 civil unrest for regime change in Egypt is examined under the following themes: the causes, patterns and effects of Egypt's civil unrest; the roles of the internet in Egypt's civil unrest for regime change, and; a critique on the responses of Egyptian government to the citizens' online activism in relation to their cyber-rights and state obligations.

\section{The Causes, Patterns, and Effects of Egypt's Civil Unrest}

Essentially, the grievances of Egyptian protesters were focused on legal and political issues including police brutality, state of emergency laws, lack of free elections and freedom of speech, uncontrollable corruption, and economic issues including high unemployment, food price inflation, and low minimum wages (SBS, 2011). The primary demands from protest organizers were the end of the Hosni Mubarak regime and the end of emergency law; freedom, justice, a responsive non-military government, and a say in the management of Egypt's resources; while Strikes by labour unions added to the pressure on government officials (The Atlantic, 2011; Defenddemocracy.org, 2011). 
The Civil Unrest began on 25th January, 2011. The uprising was mainly a campaign of non-violent civil resistance, which featured a series of demonstrations, marches, acts of civil disobedience, and labour strikes. Millions of protesters from a variety of socio-economic and religious backgrounds demanded the overthrow of the regime of Egyptian President Hosni Mubarak. Despite being predominantly peaceful in nature, the revolution was not without violent clashes between security forces and protesters. The uprising took place in Cairo, Alexandria, and in other cities in Egypt, following the Tunisian Revolution that saw the overthrow of the long-time Tunisian president. On 11 February, following weeks of determined popular protest and pressure, Mubarak resigned from office.

There were up to 846 deaths reported, and over 6,000 were injured (Almasry-alyoum.com, 2011). The capital city of Cairo was described as "a war zone," and the port city of Suez was the scene of frequent violent clashes. The government imposed a curfew that protesters defied and that the police and military did not enforce (Almasry-alyoum.com, 2011). The presence of Egypt's Central Security Forces police, loyal to Mubarak, was gradually replaced by largely restrained military troops. In the absence of police, there was looting by gangs that opposition sources said were instigated by plainclothes police officers. In response, watch groups were organised by civilians to protect neighbourhoods (Fleishman and Edmund, 2011; Al Jazeera English, 2011; Hauslohner, 2011; World Tribune, 2011; Stirewalt, 2011).

On the "Day of Revolt", 25th January, 2011, Protests erupted throughout Egypt, with tens of thousands of protesters gathered in Cairo and thousands more in cities throughout Egypt. The protests targeted President Hosni Mubarak's government, and mostly adhered to non-violence. On 26 January 2011, the Egyptian government resorted to "Shutting down the Internet and Mobile Services" after several Facebook groups were created and tweets (from Twitter) called for mass demonstrations (Cowie, 2011). This was done to cripple the protesters' main organizational tools and to impede the flow of news and people. On 28 January 2011, called the "Friday of Anger", more serious protests continued with demonstrations in Cairo and other Egyptian cities after Friday prayers. Prisons were opened and burned down, allegedly on orders from then-Minister of the Interior Habib El Adly. Prison inmates escaped en masse, in what was believed to be an attempt to terrorise protesters. Police forces were withdrawn from the streets, and the military was deployed and International fears of violence grew. President Hosni Mubarak made his first address to the nation and pledged to form a new government. Later that night, clashes broke out in Tahrir Square between revolutionaries and pro-Mubarak demonstrators, leading to the injury of several persons and the death of some individuals. On 29 January 2011, military presence in Cairo increased. A curfew was declared, but was widely ignored as the flow of defiant protesters to Tahrir Square continued throughout the night. The military reportedly refused to follow orders to fire live ammunition, and exercised restraint overall. On 1 February 2011, Mubarak made another televised address and offered several concessions. He pledged to not run for another term in the elections planned for September, and pledged political reforms. He stated he would stay in office to oversee a peaceful transition. The statement only ignited small but violent clashes between pro-Mubarak and anti-Mubarak groups. On 2 February 2011, tagged "Battle of the Camel" violence escalated as waves of Mubarak supporters met anti-government protesters, and some Mubarak supporters rode on camels and horses into Tahrir Square, wielding swords and sticks. President Mubarak reiterated his refusal to step down in interviews with several news agencies. Incidents of violence toward journalists and reporters escalated amid speculation that the violence was being encouraged by Mubarak as a way to bring the protests to an end. On 6 February 2011, A multifaith Sunday Mass is held with Egyptian Christians and Egyptian Muslims at Tahrir Square. Negotiations involving Egyptian Vice President Omar Suleiman and representatives of the opposition commenced amid continuing protests throughout the nation. The Egyptian army assumed greater security responsibilities, maintaining order and guarding The Egyptian Museum of Antiquity. Suleiman offered reforms, while others of Mubarak's regime accused foreign nations, including the US, of interfering in Egypt's affairs. On 10 February 2011, Mubarak formally addressed Egypt amid speculation of a military coup, but rather than resigning (as was widely expected), he simply stated he would delegate some of his powers to Vice President Suleiman, while continuing as Egypt's head of state. Reactions to Mubarak's statement were marked by anger, frustration and disappointment, and throughout various cities there was an escalation of the number and intensity of demonstrations.

On 11 February 2011, the "Friday of Departure", Massive protests continued in many cities as Egyptians refused the concessions announced by Mubarak. Finally, at 6:00 pm local time, Suleiman announced Mubarak's resignation, entrusting the Supreme Council of Egyptian Armed Forces with the leadership of the country. Nationwide celebrations immediately followed. On 13 February 2011, the Supreme Council dissolved Egypt's parliament and suspended the Constitution in response to demands by demonstrators. The council declared that it would hold power for six months or until elections could be held. Calls were made for the council to provide more details and specific timetables and deadlines. Major protests subsided but did not end. In a gesture to a new beginning, protesters cleaned up and renovated Tahrir Square, the epicenter of the demonstrations, although many pledged they would continue protests until all the demands had been met. On 17 February 2011, the army stated it would not field a candidate in the upcoming presidential elections. Four 
important figures of the former regime were detained on that day: former interior minister Habib el-Adly, former minister of housing Ahmed Maghrabi, former tourism minister Zuheir Garana, and steel tycoon Ahmed Ezz. On 2 March 2011, the constitutional referendum was tentatively scheduled for 19 March 2011. On 3 March 2011, Ahmed Shafik stepped down as Prime Minister and was replaced by Essam Sharaf. On 5 March 2011, several State Security Intelligence (SSI) buildings were raided across Egypt by protesters, including the headquarters for Alexandria Governorate and the main national headquarters in Nasr City, Cairo. Protesters stated they raided the buildings to secure documents they believed to show various crimes committed by the SSI against the people of Egypt during Mubarak's rule (Al Jazeera English, 2011; Alastair, 2011). On 6 March 2011, protesters acquired evidence of mass surveillance and vote rigging from the Nasr City headquarters,, and noted rooms full of videotapes, piles of shredded and burned documents, and cells where activists recounted their experiences of detention and torture (Carlstrom, 2011). On 19 March 2011, the constitutional referendum was held and passed by 77.27\% (referendum.eg, 2011). On 23 March 2011, the Egyptian Cabinet ordered a law criminalising protests and strikes that hamper work at private or public establishments. Under the new law, anyone organising or calling for such protests would be sentenced to jail and/or fined. On 1st April 2011, the "Save the Revolution" day, the demonstrators filled Tahrir Square for the largest protest in weeks, demanding that the ruling military council move faster to dismantle lingering aspects of the old regime, trial for Hosni Mubarak, Gamal Mubarak, Ahmad Fathi Sorour, Safwat El-Sherif and Zakaria Azmi as well. On 8 April 2011, the "Friday of Cleaning", the demonstrators gathered at Tahrir Square, criticizing the ruling Supreme Council of the Armed Forces for not following through on revolutionary demands. They demanded the resignation of regime figures that had remained in office and the removal of Egypt's public prosecutor due to the slow pace of investigations of corrupt former officials. On 27 May 2011, the "Second Friday of Anger" ( also called "Second Revolution of Anger" or "The Second Revolution"), demonstrators converged again at Tahrir Square, Alexandra, Suez, Ismailia, Gharbeya and other areas and demanded No Military Trials for Civilians, and that the Egyptian Constitution be made before the Parliament Elections and for all the old regime gang and those who killed protestors in January and February to be put on fair Trial.

International response to the protests was initially mixed though most called for peaceful actions on both sides and moves toward reform. Most Western governments expressed concern about the situation. The governments of different countries like US, Israel, Great Britain, Japan and Nigeria issued travel advisories and warnings, and eventually evacuated their citizens. Even multinational corporations evacuated their expatriate workers. Essentially, international reactions have varied: most Western states accepted the continuation of peaceful protests but also expressed concern for the stability of the country and the region. The United States, Britain, France, and Germany issued calls for reforms and an end to violence against peaceful protesters. Many states in the region expressed concern and supported Mubarak, in particular Saudi Arabia, who "strongly condemned" the protests, while others, like Tunisia and Iran, supported the protests (CNN, 2011). Israel was most cautious for a change, with Israeli Prime Minister Benjamin Netanyahu asking his government ministers to maintain silence, and urging Israel's US and European allies to curb their criticism of President Mubarak. NonGovernmental Organisations like Amnesty International also expressed concern about the protests and the ensuing heavy-handed state response.

After the resignation of Mubarak, many nations, leaders, and organizations hailed the end of the regime. There were celebrations in Tunisia, and Lebanon. World leaders including Angela Merkel, David Cameron joined in praising the Revolution (Baird-Remba, 2011). United States President Barack Obama praised the achievement of the Egyptian people and encouraged other activists by saying "let's look at Egypt's example" (Obama, 2011). Amid the growing concerns for the country, on 21 February, David Cameron, Prime Minister of the United Kingdom, became the first world leader to visit Egypt 10 days after Mubarak was ousted as the president. On March 15 United States Secretary of State Hillary Clinton visited Egypt, she was the highest ranking US official to visit Egypt after the handover of power from Mubarak to the military. Clinton urged the military leaders to begin the process of a democratic transition and offer support to those who had been protesting, as well as reaffirming ties between the two nations (Thomson, 2011).

Meanwhile, though the civil unrest resulted in the deaths of many Egyptians, it successfully brought down the 30-year authoritarian regime of Hosni Mubarak, facilitated the formation of a new government, put arrangements in motion for social, political, legal and economic reforms. These outcomes of the revolution are presumably capable of addressing the initial causes of the civil unrests such as police brutality, repressive state of emergency laws, lack of free elections and freedom of speech, uncontrollable corruption, and economic issues like high unemployment, food price inflation, and low minimum wages.

\section{The Roles of the Internet in Egypt's Civil Unrest for Regime Change}

The use of the Internet as a social media for online activism was extensive in Egypt. As one Egyptian activist succinctly tweeted during the protests there, "We use Facebook to schedule the protests, Twitter to coordinate, and YouTube to tell the world" (Miller-McCune, 2011). It is readily believed that a handful of 
people through Facebook, Twitter, and blogging sparked this uprising. Many believe Wael Ghonim was the first contributor to spark the Egypt revolution when he created a Facebook page dedicated to Khaled Saeed entitled "We are All Khaled Saeed". Saeed was an Egyptian business man beaten to death by police in June 2010 in retaliation to a video he posted showing Egyptian police sharing the spoils of a drug bust. The Facebook page blew up to over 400,000 followers, creating an online arena where protestors and those discontent with the government could gather, vent, and organise. The page called for protests on 25 January, Known as the Day of wrath. Hundreds of thousands of protestors flooded the streets to show their discontent with the murder and the corruption within their country. Ghonim was jailed and released 12 days later. Ghonim has also gained quite a large following through his Twitter account where he has been creating a narrative of the events happening day to day in Egypt. Another major contributor is Egyptian activist and member of the April 6 movement Asmaa Mahfouz. A week before the first protest, she posted a video urging the Egyptian people to meet her at the Tahrir Square, rise up against the government, and demand democracy. In the video she also spoke of 4 protesters who had set themselves on fire in revolt against the 30 years they had lived in poverty and degradation. On 24th January, she again posted a video chronicling the efforts that people had made to support the protest from printing posters to creating flyers. The videos were first posted to Facebook, then to YouTube where they went Viral in Egypt within a matter of days. The day after her last blog posting hundreds of thousands of Egyptians poured into the streets in protest. Though these two are credited with being the first social media faces of this revolution, since the 25th January, people have posted videos, tweeted, and wrote Facebook comments to keep the world abreast of the turmoil in Egypt (CNN, 2011). Including videos posted of a badly beaten Khaled Saeed, disproving the first claims by the police that he had choked to death. Notably, The Facebook group set up for the event attracted 80,000 attendees (YouTube.com, 2011).

As with Iran and Tunisia, much of the news the rest of the world got about the protests in Egypt was coming from the citizens there who were using the internet to upload videos and first hand accounts. Even the foreign press most of the times relies at least partially on the internet to file their reports. The Egyptian government took the radical step of cutting off their country from the internet. But this action of cutting off a country entirely from the internet does not end with crippling the communication channel of protesters to hinder mobilisation and curtail international publicity, it extends to the stagnation of internet-based businesses and activities of international actors who ordinarily should not have been affected.

\section{A Critique on the Egyptian Government's Censorship of the Citizens' Online Activism}

In response to the use of the internet in promoting the civil unrest, Mubarak's government began a comprehensive Online Surveillance and eventually shut down Internet and Mobile Services on 26th January, 2011 for two reasons: to reduce mass mobilization of the protesters, and curtail international publicity. The Egyptian government wasted no time in tightening their control of the internet. Since protestors were using their mobile phones to organize, the Egyptian government cut off mobile phone services from the internet. This resulted in Egyptian citizens opening up their home Wi-Fi security, allowing protestors within range to use their internet access to get around the government blockade. Meanwhile, the Egyptian government took the following technical measures to control the citizens' online activism:

1. monitoring individuals' internet access;

2. blocking by keywords or phrases;

3. disabling user's Internet access;

4. Filtering Internet contents;

5. Online Surveillance;

6. Shutting down the internet and mobile services;

These measures allowed for the regulation and control of all incoming and outgoing Internet traffic and mobile services. The government intercepted messages from mobile phones, computers and other communication devices. It also blocked websites in the interest of national security. This attracted diverse opinions in relation to the rights of the citizens and governments over the use of the Internet. While the optimists share the view that the citizens should enjoy the relative freedom to use the internet without restraints; the pessimists argue that the use of the internet by the citizens should be dependent on the extent to which government of the country permits given the security implications for the state. The issue of interest here is the extent to which the citizens used the internet to criticise government policies, programmes, and activities. Although the government was right under situation to censor citizens access to the internet (e.g. either by engaging in comprehensive online surveillance of citizens internet accounts against the rules of privacy, harvesting account passwords); it was not worthwhile shutting down the internet operating system entirely because it also hampered the online transactions of foreign embassies, foreign investors and companies who could not have been responsible for the crisis. Besides, internet and cellular service would be at least as much a stabilizing force as it would be a destabilizing force. In the event of civil unrest there would be many relevant voices calling for calm and for non-violence. Shutting off the internet silenced those voices along with the 
voices of those trying to organize protests. Hence, there should not be any such legislation along the lines of Protecting Cyberspace as a National Asset. Instead, there should be legislation that would specifically bar the government from shutting down internet or cellular connectivity for citizens, and that would bar telecommunication providers from "voluntarily" complying with "requests" from the government that they stop providing connectivity to persons (Philip, 2011). The government can through comprehensive online surveillance detect and punish persons found to constitute threats to national security under the provisions of cyber-laws.

\section{Conclusion}

The internet has been an essential but controversial tool for democratic activism and the consequent regime change. It has immensely contributed in mobilizing the 2011 civil unrest in Egypt which brought about the regime change that occurred. The mobilisation for the civil unrest was done through the online social media: Facebook, Twitter, and YouTube. In view of Egypt's experience, it is important to submit that as long as the citizens have their cyber-rights of privacy, freedom of expression, and access to information; the government also has the obligation to guarantee national security by regulating the internet operations of the users, censor the contents of their online transmissions, make and enforce cyber-laws against cybercrimes. Nevertheless, the internet operating system should not be censored through extreme technical measures like shutting down as they will also stifle its stabilizing roles; instead, legal and ethical measures should be applied.

\section{References}

[1]. Alastair, L. (8 March 2011). "Egyptians demand secret police give up torture secrets". $\quad$ BBC $\quad$ News. $\begin{array}{lllll}\text { http://www.bbc.co.uk/news/world-middle-east } & \text { 12674714. Retrieved } 8 \text { March 2011. } & & \\ \text { Aliya, (2010): "Internet isn't the agent of regime change some hoped for"; }\end{array}$ Online:http://www.nextgov.com/nextgov/ng 20100525 5807.php?oref opnews

[3]. Al Jazeera English (2011): "Looting spreads in Egyptian cities"; http://english.aljazeera.net/news/middleeast/2011/01/201112917592626 521.html. Retrieved 1 February 2011.

[4]. Almasryalyoum.com(2011): Egypt's Civil Unrests; Online:http://www.almasryalyoum.com/node/385 40. Retrieved 4 April 2011

[5]. Ashfaq, S. (2011): "US and the Civil Unrest of the Middle East"; Online: http://pakistananalysis.com

[6]. Baird-Remba, R. (2011): "Mubarak Steps Down: Reactions World."Online:http://www.allmediany.com/details news article.php?n ws artid=658. Retrieved 9 April 2011.

[7]. Carlson, Nicholas (January 5, 2011). "Goldman to clients: Facebook has600 million users". MSNBC. http://www.msnbc.msn.com/id/40929239/ns/technology and sciencetech and gadgets/. Retrieved February 11, 2011.

[8]. Carlstrom, Gregg (6 Mar 2011). "A first step towards prosecutions?". AlJazeera. http://english.aljazeera.net/indepth/spotlight/angerin egypt/2011/03/2011368410372200.html

[9]. Cloud, J. (December 16, 2006). "The Gurus of YouTube"; In Time Magazine Online: http://www.time.com/time/printout/0,8816,1570721,00.html.

[10]. CNN (2011): "Egypt Protests Draw Mixed Reaction in Region". Online: http://articles.cnn.com/2011-01 29/world/egypt. middle.east.reaction 1 egyptian-people-egyptianpresident-hosni-mubarak-populous-arab-nation? s=PM:WORLD. Retrieved 9 April 2011.

[11]. Cowie, J. (2011):"Egypt Leaves the Internet".Renesys.com. http://www.renesys.com/blog/2011/01/egypt-leaves-the-internet.shtml. Retrieved 21 March 2011.

[12]. Defenddemocracy.org.(2011):"Defending Democracyin Egypt”, online: http://www.defenddemocracy.org/ index.php?option $=$ cocontent\&task=vi $\quad$ w\&id=11792083\&Itemid=347. Retrieved 11 February 2011.

[13]. Defenddemocracy.org (2011): "Trade unions: the revolutionary social network at play in Egypt and Tunisia";Online: http://www.defenddemocracy.org/index.php?option=com cont $\quad$ nt\&task=view\&id=11792083\&Itemid=347. Retrieved 11 February 2011.

[14]. Fleishman, J. and Edmund S. (2011). "Unease in Egypt as police replaced by army, neighbors band against looters"; in The Seattle Times: Online: http://seattletimes.nwsource.com/html/nationworld/2014078461 egypt3 html. Retrieved 1 February 2011.

[15]. Guerra, R. (2011): "US Policy of Regime Change in the Middle East"; online:http:// pakistananalysis.com

[16]. Hauslohner, A. (2011): "The Army's OK now".Time.com.http://www.time.com/time/world/article/0,8599,2045124,00. ml\#ixzz1 froWYuj. Retrieved 1 February 2011.

[17]. Hopkins, J. (October 11, 2006). "Surprise! There's a third YouTube co founder". USA Today. http://www.usatoday.com/tech/news/2006-10-11 youtube karim x.htm. Retrieved November 29, 2008.

[18]. http://referendum.eg/84-slideshow/158-2011-03-20-19-09-58.html. Retrieved 20 March 2011.

[19]. Johnson D.R. and Post, D. G. (2005): "Law and Borders: The Rise of Law in Cyberspace"; http://www.cli.org/X0025 LBFIN.html.

[20]. Lessig, L. (2011): "Code and Other Laws of the Cyber Space"; Online: http://www.cyberlaws.com/accessed-22/06/11

[21]. Miller-McCune, M. (2011): "The Arab Uprising's Cascading Effects"; Online: http://www.miller-mccune.com/politics/thecascading-effects-of-the arab spring-28575/. Retrieved 6 March 2011.

[22]. Obama, B. (2011): "Follow Egypt's Example, Obama Tells Mideast."; http://www.alarabiya.net/articles/2011/02/15/137779.html. Retrieved $9 \quad$ April 2011.

[23]. Open Net Initiative (2011): "All Content related to China". Online: http://www.opennetinitiative.net/studies/china/.

[24]. Philip(2011): "Would we lose internet service if there were riots?" $\underline{\text { http://www.philipbrewer.net/2011/01/28/would-we-lose- }}$ internet-service if-there-were-riots/

[25]. Staffwriter (2011). "Egypt Crisis: Country Braced for 'March of a Million'" in, The Daily Telegraph (London); Online: http:/www.telegraph.co.uk Retrieved 2 February 2011. 
[26]. SBS, (2011): "Q\&A: What's Behind the Unrest?". $\quad$ http://www.sbs.com.au/news/article/1473531/Q\&A--What-s-behind-the unrest-. Retrieved 29 January 2011.

[27]. Stirewalt, C. (31 January 2011). "Egypt: From Police State to Military Rule". Fox

News. http://www.foxnews.com/politics/2011/01/31/egypt-police state-military-rule/. Retrieved 1 February 2011.

[28]. The Atlantic (2011): "Egyptian Activists' Action Plan: Translated". http://www.theatlantic.com/international/archive/2011/01/egyptian activists-action-plan-translated/70388/.

[29]. Thomson (2011): "Hillary Clinton Egypt Trip Marks Highest Level SinceMubarak'sOuster".Online:http://www.huffingtonpost.com/2011/03/15/hi ary-clinton-egypt arrives_n_835897.html. Retrieved 9 April 2011.

[30]. Trout, B. (2007). "Cyber Law: A Legal Arsenal For Online Business", New $\quad$ York: World Audience, Inc.

[31]. Weber, T. (March 2, 2007). "BBC strikes Google-YouTube deal". BBC. http://news.bbc.co.uk/1/hi/business/6411017.stm. Retrieved January 17, 2009.

[32]. World Tribune (31 January 2011): "Mubarak plays last card, the army; Police vanish"; online: http://www.worldtribune.com/worldtribune. Retrieved 1 February 2011.

[33]. YouTube.com (2008): "YouTube law fight 'threatens net"'. BBC News: May 27, 2008. http://news.bbc.co.uk/1/hi/technology/7420955.stm. Retrieved May 28, 2008. 